\title{
Abbas Kiarostami Filmlerinde \\ Gerçekçilik: Yakın Çekim (Nema-ye \\ Nazdik - 1990) Filminin Nokta \\ Metaforuyla Yeni Bir Okuması
}

\section{Murat Şahin}

Öz

Bu çalışmada, Abbas Kiarostami'nin yönetmenliğini yaptığı Yakın Çekim (1990) filminin, sinema ve gerçekçilik bağlamında analizi yapılmıştır. Analiz yapııırken nokta metaforundan yararlanılmıştır. Nokta metaforu, gerçeğin bir nüvesi, gerçekliğe ulaşma çabasının bir izdüşümü ve kendinden hareketle gerçeğin çoğaltılması bakımından önem taşımaktadır. Bu bakımdan nokta metaforunun sağladığı anlam zenginliğinden yararlanılarak filmin sinematografik ögeleri olan yakın çekim kullanımı, senografik ögelerin tercihi ve ses kullanımı gibi unsurlar üzerinden analizi yapılmıştır. Yakın Çekim filminde yönetmen Abbas Kiarostami, nokta olan bir gerçeğin peşine düşmektedir. Kiarostami, bu gerçeğin üzerini örten perdelerin aralanmasını istemektedir. Gerçekçi film kuramcıları, gerçeğin çok boyutlu olduğunu ve ortaya çıkarılmasının gerektiğini ifade ederler. Filmde gerçeğin ortaya çıkarılması için yakın çekim, diyalog, ses ve çeşitli senografik unsurlardan yararlanılmıştır. Filmde nokta metaforunun bir uzantısı olarak gerçeğe ulaşma adına yakın plan çekim yönteminin sıklıkla kullanıldığı görülmüştür. Kurmaca ve gerçek arasındaki ince sınırda ilerleyen filmde, gerçeklik yanılsaması da yer almaktadır. Ses unsuru da yine gerçekliği tamamlayan bir öge olarak kullanılmıştır. Son olarak senografik ögelerin nokta metaforuyla bir arada düşünüldüğünde gerçeğe ulaşma adına işlevsel bir rolü olduğu görülmüştür.

Anahtar Sözcükler: Gerçeklik, Gerçekçilik, Nokta Metaforu, Kiarostami, İran Sineması, Yakın Çekim

\author{
MURAT ŞAHIN \\ Arş. Gör. Dr. \\ Ondokuz Mayıs Üniversitesi \\ murat.sahin2@omu.edu.tr \\ ORCID ID: 0000-0001-7533-8602
}

SELÇUK ILETIŞIM DERGISI 2021; 14(3): 1341-1370

doi: $10.18094 /$ JOSC.883646

Geliş Tarihi: 20.02.2021 Kabul Tarihi: 05.04.2021 Yayın Tarihi: 25.07.2021 


\title{
Realism in the Abbas Kiarostami's \\ Film: A New Reading of Close Up \\ (Nema-ye Nazdik - 1990) with The \\ Point Metaphor
}

JOURNAL OF SELÇUK

COMMUNICATION 2021;

14(3): 1341-1370

doi: $10.18094 /$ JOSC.883646

\section{Murat Şahin}

\begin{abstract}
In this study, the movie Close Up (1990) directed by Abbas Kiarostami was analyzed in the context of cinema and realism. Point metaphor was used while analyzing. The point metaphor is a core of reality, a projection of the effort to reach reality. The point metaphor is important in reproducing the truth based on self. In this respect, using the richness of meaning provided by the point metaphor, the film's of cinematographic elements were analyzed through elements such as the use of close-up, the preference of the scenographic elements, and the use of sound. In Close-Up, director Abbas Kiarostami pursues a truth that is the point. Kiarostami wants the curtains covering this reality to be opened. Realistic film theorists state that reality is multidimensional and must be revealed. Close-up, dialogue, sound, and various scenographic elements are used to reveal the truth in the film. As an extension of the point metaphor in the film, it has been observed that the close-up method is frequently used to reach the truth. The illusion of reality is also included in the film, which moves along the thin border between fiction and reality. The sound element is also used as an element that complements reality. Finally, when the scenographic elements are considered together with the point metaphor, it is seen that they have a functional role in reaching the truth.
\end{abstract}

Keywords: Reality, Realizm, Point Metaphor, Kiarostami, Iranian Cinema, Close Up

\author{
MURAT ŞAHIN \\ Res. Ass. Dr. \\ Ondokuz Mayıs University \\ murat.sahin2@omu.edu.tr \\ ORCID ID: 0000-0001-7533-8602
}

JOURNAL OF SELÇUK COMMUNICATION 2021; 14(3): 1341-1370

doi: 10.18094/ JOSC.883646 


\section{GiRiş}

Gerçekçilik ve biçimcilik yaklaşımı, sinemanın başlangıından itibaren kuramsal tartışmaların önemli bir yönünü oluşturur. Gerçekçilik yaklaşımını savunan kuramcılar için sinema, gerçeğin ortaya çıkarılmasında geniş imkan ve potansiyele sahiptir. Gerçekçilik yaklaşımı gerçeğin ifadesinde hem içerik hem de biçim bakımından çeşitli ögelere sahiptir (Andrew, 2010, s. 187-189).

Sinema alanında gerçekçilik yaklaşımına yeni bir boyut kazandırmak amacıyla bu çalışmada sinema ve tasavvuf ilişkisinden hareketle nokta metaforu üzerinden bir analiz yapılacaktır. Gerçekçiliğin sinemaya yönelik, gerçekliğin çok boyutlu olduğu ve sinemasının bu gerçekliği yansıtabilecek bir araç olarak görüldüğü (Bazin, 2007, s. 10) şeklindeki yaklaşımının yanında sinema ve tasavvuf ilişkisinin de bu yönde okunabileceği düşünülmektedir. Bu anlamda çalışmanın bir diğer kavramsal yönünü sinema tasavvuf iliş̧kisi oluşturmaktadır. Geniş bir alan olan bu konunun, bu çalışma için ilgili yönünü zahir/batın ve vahdet/kesret kavramları oluşturmaktadır. Sinema gerçekliğin çok katmalı yapısının, gizli yönlerinin ve gerçek dünyada görülemeyenlerin ortaya çıkarılmasına olanak tanımaktadır (Kracauer, 2015, s. 516518). Bu anlamda hakikate ulaşmak da yine tasavvufi düşüncenin bir özelliğidir. Bu anlamda sinemadaki gerçekçi yaklaşım ve tasavvufun gerçeğe yaklaşımı arasında bağ kurulabilir. Yine çalışma için önemli olan bir diğer kavram da nokta metaforu'dur. Gerçeğin tekliği ve çokluğu, saklı kalması ya da açığına çıkarılması bakımından (Yücer, 2017, s. 62) nokta metaforunun, işlevsel bir yönünün olduğu düşünülmektedir. Aynı zamanda nokta metaforu çalışmada analiz edilecek filmin çözümlenmesi açısından önem taşımaktadır.

Çalışmanın çıkış noktasını, gerçekliğin katmanlı yapısını aralayarak filmlerde gerçeğin yansımalarını ele alan gerçekçi akım yaklaşımı ve hakikate ulaşmayı kendine ilke edinen tasavvufu bir arada düşünme çabası oluşturmaktadır. Özellikle, tasavvufun kullanmış olduğu nokta metaforu, hakikati anlama adına önem taşımaktadır. Sinema ve tasavvuf ilişkisinde tasavvuf perspektifinden konuya yaklaşıldığında "zahir-batın" ve "vahdet-kesret" kavramlarının önem taşıdığı görülmektedir. Çalışmanın bir anlamda sınırılığı oluşturması bakımında sadece tasavvufta sıkça kullanılan nokta metaforu ile sinemanın bir arada düşünülmesi ele alınacaktır. Bu açıdan bakıldığında gerçeklik ve hakikat kavramlarına yaklaşım anlamında sinema ve tasavvufun bir arada düşünülebileceği görülmektedir. Gerçekçi yaklaşımın önemli ögelerinden olan "yakın çekim, düşünümsellik, gerçeklik yanılsamasının" yanında "ses ve 
senografik ögelerin" kullanımı gibi sinematografik unsurların nokta metaforıyla çözümlenmesi, çalışmanın analiz kısmını oluşturmaktadır.

Özetle, "nokta metaforunun, sinematografik unsurlar ile birlikte düşünüldüğünde gerçeğe ulaşma girişiminde nasıl bir kullanıma sahip olduğu" bu çalışmanın problemini oluşturmaktadır.

\section{KAVRAMSAL ÇERÇEVE}

Çalışmanın bu bölümünde sinemada gerçekçilik, Yeni İran Sineması, Abbas Kiarostami filmleri ve nokta metaforuna değinilecektir.

\section{Sinema ve Gerçekçilik}

Felsefi bir kavram olarak gerçek, "varlı̆ıın kesin olan, görüntüyle ilgili olana karşıt olan şeylerle ilgili olan(ı)" ifade ederken, gerçekçilik ise "varlığın düşünceden bağımsız olduğunu öne süren öğreti" anlamına gelmektedir (Timuçin, 2004, s. 228). Gerçekçilik, sanatın farklı alanlarında etkili olmuş bir anlayıştır. Sanatta gerçekçilik akımı, sanatçının duygu ve hayal dünyasından ziyade insan ve toplum temelli bir anlayışı odağına almaktadır. Gerçekçilik akımında yaşam, olduğu gibi sanat eserine yansıtılmak istenir (Moran, 2014, s. 54-56). Ancak, gerçekliğin olduğu gibi sanat eserine aktarılabilirliği fikri yanında, "gerçekliğin kırılgan" olabileceği (Zizek, 2005, s. 33) anlayışı da bulunmaktadır. Yine bu gerçekliğin, zihinsel gerçeklik algısı üretiminin yanında bu etkinin nasıl toplumsal gerçekliğe dönüşebildiğine dair açıklamalar da vardır (Gültekin, 2020).

Sinema sanatı, ilk ortaya çıktığı yıllardan itibaren yapılmaya başlanan kısa filmler ve belge filmleriyle, sonraki yıllarda "biçimci ve gerçekçi" akım olarak adlandırılan iki yönelime evrilmiş̧ir. Bu iki yönelimin bir ucunda, Auguste ve Louis Lumiere'in yapmış olduğu kısa filmler varken ve bu anlayış gerçekçi yaklaşımın temelini oluştururken diğer tarafta ise George Melies'ın kurmaca filmleriyle temelleri atılan biçimci yaklaşım bulunmaktadır. Bu bakımdan, sinema sanatının sonraki yıllarda biçimci ve gerçekçi perspektiften değerlendirilmesinin temeli Lumiere Kardeşler ve Melies'ın anlayışına dayandırılır. Sinemada gerçek olan malzeme üzerinde yönetmenin duygu ve hayal dünyasının etkisiyle dönüşüm yaşatarak mı yoksa gerçeği olduğu gibi sanat eserine yansıtılması meselesi biçimci ve gerçekçi anlayışın temel sorunsalı oluşturur. Lumiere Kardeşler, Trenin Gara Girişi (L'arrivée d'un train à La Ciotat, 1895) ve Fabrikadan Iş̧̧ilerin Çııışı (La sortie de I'usine Lumière à Lyon, 1895) gibi kısa filmlerinde tek planda ve 
hareketsiz kamerayla gerçekliğin bir kesitini sunarlar. Diğer taraftan Melies ise Aya Yolculuk (Le Voyage Dans La Lune, 1902) filminde tek planda ve hareketsiz kameraya rağmen farklı görüntüleri birleştirerek bir anlam oluşturur. Bu bakımdan gerçekçi kuramın Lumiere Kardeşler'in çekim tarzından etkilendiği ve biçimci kuramın ise Melies'ın yaklaşımını takip ettiği söylenebilir (Monaco, 2001, s. 373-378).

Biçimci kuram, filmin malzemesi üzerinde oynayarak gerçeğin ötesine geçmeyi amaçlamaktadır (Gürata, 2010, s. 63). Biçimciler arasında Sergei Eisenstein, Rudolph Arnheim, Bela Balâzs ve V. I. Pudovkin gibi yönetmen ve kuramcılar bulunmaktadır. Biçimci yaklaşımın klasik anlatı sineması ilkelerini taşıyan bir film diline sahip olduğu söylenebilir. Gerçekçi kuram ise yaşanan gerçekliğin olduğu gibi kayıt altına alınması ilkesine dayanmaktadır (Gürata, 2010, s. 63). Siegfried Kracauer (2015) ve Andre Bazin'in (1995) teorik çerçevesini çizdikleri gerçekçi yaklaşım izleyiciden filme katılım istediği, klasik anlatı sinemasının anlatı kodlarını yapıbozuma uğratmayı amaçladığı söylenebilir.

Gerçekçi kuramcılar, filmde montajın görünmez kılınması gerektiğini ifade ederler. Kracauer da sinemanın, kurguya dayalı bir sanat olmayıp fotoğrafa dayandığını, fotoğrafın nesnesiyle ayrılmaz ilişkisinin olduğunu ve sinemanın da fotoğraf ve nesne arasındaki bu birlikteliği yansıtması gerektiğini savunur (Andrew, 2010, s. 193-195). Sinemada gerçekçi anlayışın ilk olarak kendini gösterdiği sinema akımının İtalyan Yeni Gerçekliği olduğu söylenebilir. Daha öncesinde Fransız Şiirsel sineması toplumsal konuları ele almasına rağmen gerçekçiliğin temel ilkeleri daha sonra atılmıştır (Coşkun, 2009, s. 132). Kracauer, Kuzeyli Nanook (Flaherty, 1922, Nanook of the North), İtalyan Yeni Gerçekçiliği akımı içindeki Yer Sarsılıyor (Visconti, 1948, La terra trema) ve Bisiklet Hirsızları (De Sica, 1948, Ladri di biciclette) gibi filmlerin gerçekçiliğin özelliklerini yansıttığını söylemektedir (2015).

Andre Bazin (2007, s. 33-34), gerçekçilik anlayışında kurguyu özellikle estetik kullanım yönüyle yadsımaz. Eisenstein ve Kuleşov gibi yönetmenlerin kurguyu, metafor ve anlam bağlama açısından kullanmalarını övmektedir. Ancak uzun çekimlerde gerçekliğin bozulmaması şartıyla görüntülerin atlanması anlamında kurgunun varlı̆ı̆ı kabul etmektedir. Ayrıca Andre Bazin, De Sica'nın Bisiklet Hırsızları filminde kurguya olan bağımlılığın terk edildiğini ve Italyan Yeni Gerçekçilik'in sinemasal kodlarını oluşturduğunu ifade eder (1995, s. 65-66).

Yeni Gerçekçi akım, gerçeğe bağlılı̆ını seçilen amatör oyuncu, doğal mekân ve doğal ışık açısından da göstermiştir (Coşkun, 2009, s. 176). Gerçekçi sinemanın ana sinematografik tercihleri alan 
derinliği, plan-sekans, uzun çekim ve kimi zaman yakın çekim olarak sıralanabilir. Bu sinematografik unsurlar sayesinde zaman ve mekân oluşturularak gerçekçilik sağlandığı söylenebilir (Bazin, 2007).

Gerçekçi kuramın sinema anlayışının yansıdığı bir diğer akım ise Fransız Yeni Dalga sineması olmuştur. Bazin'in büyük katkısının olduğu Le Chaiers du Cinema dergisi etrafında toplanan bir dizi yönetmen ve sinema kuramcısı, gerçeklik ve modern sinema bağlamı altında yeni bir sinema dilli yaratmışlardır. François Truffaut ve Jean Luc Godard, bu sinema akımının önde gelen isimleri arasında bulunurlar (Coşkun, 2009, s. 203). Auteur kuramının da ortaya çıtığı Yeni Dalga Sineması, klasik anlatı sinemasının temel anlatı kodlarına karşı modern anlatının kodlarını geliştirmiştir. Böylece gerçeklik anlayışının filmlere yansıtııması üzerine yeni stiller oluşturmuşlardır (Kovacs, 2010).

Sinema aracılığıyla yönetmen yaptığı filmlerde yansıtmak istediği veya yeniden oluşturmak istediği gerçekliğin kırılgan ve parçalı yapıya sahip olduğunu unutmamalıdır. Yine izleyici de aynı şekilde "dünyaya açılan bir pencere olmayıp sadece üzerine kayıt yapılan bir yüzey olan ekranda" kendisine sunulanın ötesinde bir "kör alanın" olduğunu bilmesi gerekir (Bonitzer, 2011, s. 84-85).

Sinemanın ortaya çıktığı ilk yıllardan itibaren tartışılmaya başlanan, gerçeğin olduğu gibi mi yoksa üzerinde oynanarak oluşturulması tartışması sonraki yıllarda da devam ettirilmiştir. Özellikle Bazin ve Kracauer gibi kuramcılar ile Yeni Gerçekçi ve Yeni Dalga Sinema akımlarıyla şekillenen gerçekçi kuramın, sonraki yıllarda da ülke sinemaları ve yönetmen sinemaları üzerinde büyük etkisi olduğu söylenebilir. Bu etkilenmenin görüldüğü sinemalardan biri de İran sinemasıdır.

\section{Yeni İran Sineması}

Yeni İran Sineması özellikle 1990'lı yıllarda uluslararası festivallerle birlikte dünya çapında tanınırlı̆ı artmasının yanında ilk önemli örneklerini devrim öncesinde vermeye başlamıştır. 1960'ı yıllarda geleneksel İran sinemasından farklı temalar ve sinematografik unsurları kullanan bu filmlerde İran kültüründen yansımalar da yer almaktaydı.

İran sanat çevresi adını, şiir ve edebiyat alanındaki başarılı yapıtlarıyla dünyaya duyurmayı başarmıştır. Şiir ve edebiyat alanındaki bu uluslararası başarı, 1970'lerde yerini sinemaya bırakmıştır. 0 zamana kadar ucuz ve popüler türlerle pek başarı sağlayamayan İran sineması, 1970'lerle birlikte İran sanat çevresinin dünyaya açılan penceresi haline gelmiştir (Dabaşi, 2013, s. 35-40). 
İran kültürü ve geleneklerinden izlerin bulunduğu Şair Faruk Ferruhzad'ın Ev Karadır (Hane-i Siyahest, 1965) filmi bu yeni sinemanın ilk örneklerinden biri kabul edilmektedir (Ferahmend, 2007, s. 110). Dariush Mehrjui'nin İnek (Gâv, 1969) filmi ise Yeni İran Sinema veya İran Yeni Dalgası'nın ilk filmi sayılmaktadır. Filmde, tek geçim kaynağı olan ineğini kaybetmesi sonucu dönüşüme uğrayan bir karakter anlatılmaktadır (Aktaş, 2005, s. 65).

İran Yeni Dalga akımının önemli kurucu yönetmenleri arasında Çocuklar ve Gençlerin Zihinsel Gelişimi Enstitüsü altında Abbas Kiarostami, Dariush Mehrjui ve Mesut Kimyayi gibi yönetmenler bulunur (Dabaşi, 2013, s. 37). Bu enstitünün yanında Farabi Enstitüsü de İran'da sinemanın gelişiminde ve desteklenmesinde önemli rol oynamaktadır. Farabi Enstitüsü'nün bir diğer özelliği de filmlerin festivallere gönderilmesi konusunda yönetmenleri cesaretlendirmesidir. Böylece filmler uluslararası arenada görünürlük ve ardından başarılar kazanmaya başlamıştı (Aktaş, 2005, s. 36). Mecid Mecidi'nin Cennetin Çocukları (1997) filmi 1999 yılında en iyi yabancı film dalında Oscar'a aday gösterilen ilk Iran filmi olmuştur. Sonraki yıllarda bu kurucu yönetmelere Cafer Panahi, Muhsin Makbalbaf gibi isimler de katılır.

1979 İran İslam Devrimi'nin birçok alanda olduğu gibi İran sineması üzerinde de etkisi olmuştur. İranlı yönetmenlerin bir kısmı ülkeyi terk ederken ülkede kalanlar ise bir belirsizlik dönemi ve sansürle yüzleşmeye başlamışlardır. Devrim öncesinde de Batı sinemasının kimliksiz ve yozlaşmış olduğu inancı devrim sonrasında da devam etmiş ve filmler İslami kurallara uygunluk kıstasıyla denetlenmeye başlamıştır (Tapper, 2007, s. 2).

Devrim sonrasında film endüstrisinin sorumluluğu, 1982 yılında Kültür ve İslami Rehberlik Bakanlı̆̆ı'na bırakılmış, filmlerin denetimi ise Film ve Sinema Şurası'na devredilmiştir. Devrimin ilk yıllarındaki belirsizliğin ardında yeni rejim, özellikle popüler filmlerle İslami düşüncenin aktarılmasına onay vermiştir. Bu arada Beyzai, Kiarostami ve Mehrjui gibi yönetmenler ise popüler filmler dışında filmler yapmaya başlarlar (Dabaşi, 2013, s. 24).

İran sinemasının temel sinematografik kodları ve anlatım kodları şu şekilde sıralanabilir: Konu ve tema olarak, sıradan insanların yaşamına odaklanan basit ve yalın hikâyeler; öykü tercihi ise gevşek öyküleme şeklinde olup karakterlerin ilişkileri rastlantısaldır. Son zamanlara kadar çoğunlukla profesyonel olmayan oyuncular tercih edilmektedir. Mekân ve aydınlatma doğal olacak şekilde seçilir. 
Kurgu ise gerçeklik bozulmayacak şekilde yapılır. Uzun planlar ve devingen kamera kullanılır. Açık uçlu anlatı bulunur ve anlatımda kesinlik yoktur.

\section{Abbas Kiarostami Filmleri}

1940 yılında İran'da dünyaya gelen Abbas Kiarostami, ülkesinin yaşamış olduğu siyasal ve toplumsal çalkantılara şahit olmuştur. Hayatının ilk on üç yıll, ülkesinin nispeten barış ve huzur içinde olduğu bir döneme denk gelmiştir. 1953 yılında bu huzurlu ortam, dış destekli bir darbeyle Şah'ın yönetime gelmesiyle sekteye uğramıştır. Şah yönetimi ülkede baskıcı bir yönetim anlayışı sergileyerek mevcut kurumları kendine bağlamış ve özgürlük alanlarını kısıtlamıştır. Bu esnada toplumun değişik kesimlerine sirayet eden rahatsızlık, gün yüzüne çıkmaya başlamıştır. Uzun bir sürgün hayatından sonra ülkesine dönen Humeyni, 1979 yılında İran Devrimi'ni gerçekleştirerek İran İslam Cumhuriyeti'ni kurmuştur. Bu devrimden bekleneni bulamayan halk, yeni bir baskı ve özgürlüklerin kısıtlandığı döneme girmiştir (Dabaşi, 2013, s. 26-35).

İran sinemasının 1970'lerde hareketlenmesi ile birlikte yönetmenler kendilerine bir üslup yaratarak bu doğrultuda filmler yapmaya başlamışlardır. Kiarostami sinemasının temel yaklaşımı, "gerçeklikler ve üretilmiş gerçeklikler arasındaki ayrımı ortaya koyarak, hakikatin geçiciliği, dönüşlülüğü ve çok yönlü yapısına dikkat çekmektedir." Kiarostami filmlerinde, "hakikate egemen olma, onu yönetme gibi bir yaklaşımdan ziyade, hakikatin çok yönlü yapısını ortaya koyarak bir dayatmadan öte ihtimalleri gözler önüne serme peşindedir." Ayrıca yönetmen insan aklının sınırlılı̆ını hatırlatarak, gerçekliğe ancak bu sınırılı̆̆ın olanakları içerisinde el değdirileceğini, hakikate ulaşmanın ise mümkün olmadığını vurgulamaktadır (Ipek, 2014, s. 118-119).

Kiarostami, filmleriyle İran halkına dünyaya farklı bakışı ve gerçekliğin sorgulanmasını hatırlatmaktadır. Kiarostami dünyayı, sıradan bakış açısından fark edilemeyen, farklı bir yönden, gerçekliğin doğası ve çok yönlülüğü çerçevesinde ele almaktadır. Kiarostami, izleyicisinin dünyayı yeniden sorgulamasını gerçekliğin sorgulanması şeklinde yapmaktadır (Dabaşi, 2013, s. 59).

Ayla Kambur Komşunun Evi Nerede? Iranlı Yönetmenler Dışarı'da Dolaşıyor adlı çalışmasında Kiarostami'nin sinema dilini şu şekilde anlatmaktadır: "Yaşamın bütünü içinden odaklanılan bir öykü, bu öyküde yer alan karakterlerin birbirlerine ayna tutan konumları, bu konumların her birinin kendi mekân ve 
çevresiyle değerlendirilişi, küçük bir gazete haberi olabilecek bir durumdan ortaya çıkarılan toplumsal renkler [...] sadeliğini yaşamdan alınan bir parçanın büyütülmesinden alan ama bu büyütme tüm anlam katmanlarını açacak şekilde konunun seçimi. Bir gerçeklik parçasını genelin içinden alıp olabildiğince büyüterek, yeniden genelin içine göndermek [...] film sanatsal aldatmacanın ne olduğuna, yönetmenle oyuncu arasındaki ilişkive, rol yapmanın ne olduğuna, sanatın yaşamdan ne kadar kopuk olduğuna, sıradan denilen insanların sanatla ilişkisine, sinemanın gerçekliğinin insanlarda yarattığı etkiye, sinemanın parayla ilişkisine kadar, çağrışımlar yaratarak izleyiciyi derinleştirir" (Kambur, 1999, s. 64-66).

Kiarostami filmlerle ve genel olarak sanatla ancak hakikatin yansımalarının gösterilebileceğini hatırlattığı söylenebilir: "Her zaman, bir film seyretmekte olduğumuz düşüncesinde olmalıyız. Çok gerçek görünse bile [...] Seyircinin bir gerçekliği değil bir film seyretmekte olduğunu görmesi için ekranın iki yanına yanıp sönen iki ok koymak isterim. Yani bir film gerçeklikten yola çıkarak bizim kurduğumuz bir şeydir. Bu yaklaşım yeni filmlerimde arttı ve daha da artacak. Daha bilgili bir seyirciye ihtiyaç duyduğumu düşünüyorum. Onları esir alıp duyguları üzerinde oynamaya karşıyım. Seyirci bu duygusal şantajdan kurtulduğu zaman kendi efendisi olacak ve olguları daha bilinçli bir gözle seyredecek. Duygusallığa kapılmadıkça kendimize ve bizi kuşatan dünyaya egemen olabiliriz"(Kalari, 1999, s. 66).

Yeni İran sineması kapsamında film yapan yönetmenlerin ortak bir özelliği anlatılarında sinema üzerine düşünmeye yer vermeleridir. Kiarostami, filmlerinde belgesel ve kurmaca arasındaki sınırda anlatısını kurmaktadır. Filmde kullandığı tekniklerle izleyiciye film izlediğini hatırlatmaktadır. Böylece geleneksel anlatı sinemasının izleyiciyi etkisi altına alan özdeşleşmeye karşı durarak filmin yapıntılığına vurgu yapmaktadır. Örneğin, Cannes Film Festivali'nde Altın Palmiye kazanan Kirazın Tadı (Ta'm e guilass, 1997) filminde intihar etmeyi düşünen ana karakterin kendisinin ölümünden sonra üzerini toprakla örtmek için bir kişiyi aradığı bir hikâye kurulur. Filmin sonuna doğru ana karakterin intihar edip etmediği konusunda izleyicide uyandırılan merak duygusu, filmin sonunda set ortamı, çalışanlar ve ana karakter gösterilerek bunun aslında bir film olduğu hatırlatılır. Böylece izleyicinin katharsis yaşamasının önüne geçilir. 


\section{Nokta Metaforu}

Çalışmanın bu bölümünde Yakın Çekim filminin analizi açısından nokta metaforu kavramlaştırmasından yararlanılacaktır. Sinema/tasavvuf ve sinema/gerçekçilik arasındaki ilişkiye bakıldığında çalışmanın temel perspektifi açısından birtakım kavramlara yer verilmesi gerekmektedir. Böylece nokta metaforu üzerinden gerçekliğe ulaşma çabasının kavramsal çerçevesi kurulmaya çalışılacaktır.

Konunun sinema yönünü gerçekçilik akımı bağlamında filmlerde çok katmanlı olan gerçeklik üzerindeki katmanların kaldırılması oluşturmaktadır. Bu anlamda Bazin ve Kracauer'in görüşleri önem taşır.

Sinema ve tasavvuf iliş̧kisinde tasavvuf perspektifinden konuya yaklaşıldığında "zahir-batın" ve "vahdet-kesret" kavramlarının önem taşıdığı görülmektedir. Özellikle çalışmanın bir anlamda sınırlılı̆ı oluşturması bakımında sadece tasavvufta sıkça kullanılan nokta metaforu ile sinemanın bir arada düşünülmesi ele alınmıştır. Bu açıdan bakıldığında gerçeklik ve hakikat kavramlarına yaklaşım anlamında sinema ve tasavvufun bir arada düşünülebileceği görülmektedir.

Ethem Cebecioğlu (2005) Tasavvuf Terimleri ve Deyimleri Sözlügü̈nde zahir-batın kavramlarını şu şekilde açıklamaktadır: "Zahir, dış, dışa ait, zuhur eden, ortaya çıkan, görünen gibi anlamları olan Arapça bir kelime. Zahir, görünen âleme de denir. Batın, Arapça, iç, öz, gizli gibi anlamları vardır. Dış anlamına gelen zahir kelimesinin zıddıdır" (s. 46-47). Yine aynı kaynakta vahdet-kesret kavramları şu şekilde ifade edilmektedir: "Vahdet, Arapça, birlik demektir. Kesrette vahdet, çoklukta birlik, yani halkın içinde, kalabalığın ortasında, tek ve bir olan Allah'ı unutmamak" (s. 355), son olarak kesret ise "Arapça, çokluk demektir. Vahdetin zıddıdır. Varlıkların varlıklarını kendilerinden bilmek, onları müstakil varlıklarla var görmektir. Mevcudatın varlığını, Allah'tan bilmeye de vahdet denir. Her varlıkta Allah'ın gücünü görmek, kesrette vahdeti görmek" (s. 201) anlamına gelmektedir.

Gerçeğe, zahiri aralayarak batına ulaşma ya da tek olan yani vahdet olan hakikate ulaşmak için çokluktan sıyrılma, kesreti aradan çıkarmak gerektiği söylenebilir. Bu açıdan sinemanın da gerçeğe ulaşma adına bu anlamda çeşitli imkanları ve benzerlikleri olduğu düşünülebilir. İncelenen filmde de yönetmenin gerçeğe ulaşma amacıyla hem filmin anlatısında hem de tekniğinde çeşitli yöntemler 
kullandığını söylemek mümkündür. Nokta metaforunun da yine bu bakımdan, gerçeğe ulaşmak için hakikat nüvesi taşıma potansiyeli barındırdığı düşünülebilir.

Nokta metaforunun Tanrı-alem-insan arasındaki ilişkiyi ortaya koymak adına işlevsel bir kullanımı bulunmaktadır. Nokta metaforunun kullanıldığı ve ifade edildiği unsurlar arasında "ilim, $\mathrm{Hz}$. Ali, vahdet noktası, hakikî güneş, eşyanın hakikatinin kaynă̆ı, Muhammedî hakikatin sırrı, Âdem'in kalbinin hakikati, insanın cisminin aslı, ilk cevher, akl-ı kül, bâtın güneşi, asıl nokta ve siyah nokta (nokta-i süveydâ)" (Noktatül Beyan Risalesinden aktaran Tabakoğlu \& Maden, 2019, s. 62) gibi unsurlar bulunmaktadır. Nokta metaforu bir benzetme amacı gütmektedir. Böylece nokta metaforıyla "damladan denizi bilmek, zerreden güneşi görmektir. Yani mesele birlik ve çokluk, çokluğun birlikten nasıl meydana geldiği ve birlik ile çokluk ilişkisidir" (Tabakoğlu \& Maden, 2019, s. 62). Yine aynı eserin bir bölümünde Fussilet sûresinin 53. ayetinin, "Kendini bilen Rabbini bilir." rivayeti ve Hz. Ali'ye nispet edilen "ilim bir nokta idi, onu cahiller çoğalttı." ve "Ben bâ harfinin altındaki noktayım" sözlerine de atıf da bulunmaktadır (Tabakoğlu \& Maden, 2019, s. 63).

Cebecioğlu, Tasavvuf Terimleri ve Deyimleri Sözlügü̈'nde (2005, s. 205) noktayı şu şekilde açıklamaktadır: "Arapça nokta, küçük parça, iş, mesele, mekân, saha anlamlarını ihtiva eden bir kelime. Tasavvufta nokta, harflerin başlangıı ve sonudur. Harflerin hepsi, noktanın yayılmasından meydana gelir, bu bakımdan harflerin hepsi, noktadadır. Bütün harfler, noktadan ibarettir. Işte tıpkı bunun gibi, bütün varlıkların suretleri, her an Allah'ın bilgisinde ta'ayyün eder, bu ta'ayyün, varlıkların zuhuruna (ortaya çıkmasına) sebep olur. Bu sebeple kâinat, gerçekte taayyün-i zâtî'nin, yani Allah'ın zâtına ait sıfatı olan bilgi (ilim) sinde belirmiş, suretlerin, yokluk âleminde zuhurundan ibarettir ve âlemlerin varlı̆ı izafí (rölatif) varlıktır."

Bu bakımdan nokta metaforunun sağladığı anlam zenginliği, ele alınan filmin, gerçekliğin kırılganlığı ve parçalı yapısının yanında gerçeğe ulaşma girişiminin analizi bakımından da önem taşıdığı söylenebilir.

\section{METODOLOJi}

Bu çalışmada, Yakın Çekim filmindeki gerçekçilik yaklaşımının nokta metaforıyla analizi yapılmıştır. Filmde yer alan gerçekçi yaklaşımın önemli ögelerinden olan "yakın çekim, düşünümsellik, 
gerçeklik yanılsamasının" yanı sıra "ses ve senografik ögelerin" kullanımı gibi sinematografik unsurların nokta metaforıyla çözümlenmesi, çalışmanın analiz kısmını oluşturmaktadır.

Bu çalışma, niteliksel tasarımda hazırlanan bir araştırmadır. Nitel araştırma "gözlem, görüşme ve doküman analizi gibi nitel veri toplama yöntemlerinin kullanıldığı, algılar ve olguların doğal ortamda gerçekçi ve bütüncül bir tarzda ortaya konul(duğu)" bir araştırma türüdür (Yıldırım \& Şimşek, 2016, s. 39).

Bu çalışmanın örneklemi ise "amaçlı örneklem tekniği" ile belirlenmiştir. Amaçlı örneklem "önceden tanımlanarak belirlenmiş amaca uygun birimlerin inceleme için seçilmesidir" (Erdoğan, 2007, s. 177).

Çalışmanın örneklemini İran sinemasının önemli yönetmenlerinden biri olan Abbas Kiarostami'nin Yakın Çekim filmi oluşturmaktadır. Bu film, kurmaca ve gerçek arasındaki konumu, sinema üzerine düşünümselliği ve gerçekçilik yanılsaması gibi özellikleri taşımaktadır. Ayrıca adından da anlaşılacağı üzere filmde "yakın çekim" kavramı, hem bir kamera tekniği olarak hem de gerçeğe ulaşma çabasının bir uzantısı olarak kullanılmaktadır. Yine sinematografik bir unsur olarak ses de gerçeğe ulaşma çabasının bir izdüşümü olarak değerlendirilebilir.

Çalışmada veri toplama tekniği olarak ise betimsel analiz kullanılmıştır. Betimsel analiz dört aşamada gerçekleşmektedir. Birinci aşamada araştırmacı araştırma sorularından, araştırmanın kavramsal çerçevesinden ya da görüşme ve gözlemlerde yer alan boyutlardan hareket ederek veri analizi için bir çerçeve oluşturur. Böylece verilerin hangi temalar altında düzenleneceği ve sunulacağı belirlenmiş olur. Ardından, araştırmacı daha önce oluşturmuş olduğu çerçeveye dayalı olarak verileri okur ve düzenler. Bu süreçte verilerin anlamlı ve mantıkı bir biçimde bir araya getirilmesi önem taşımaktadır. Bu aşamadan sonra araştırmacı düzenlemiş olduğu verileri tanımlar. Bunun için gerekli yerlerde doğrudan alıntılara da başvurmak zorunda kalabilir. Bu sürecin sonunda araştırmacı tanımlamış olduğu bulguları açıklar, ilişkilendirir ve anlamlandırır. Araştırmacı bu aşamada ayrıca yapmış olduğu yorumları daha da güçlendirmek için bulgular arasındaki neden sonuç ilişkilerini açıklar ve ihtiyaç duyulması durumunda farklı olgular arasında karşılaştırma yapar (Yıldırım \& Şimşek, 2016, s. 158).

Bir metin içeriğinin betimsel analiz ile çözümlemesi mümkündür. İçerik, iletilebilen sözcükler, anlamlar, resimler, semboller, düşünceler, temalar veya herhangi bir iletiye gönderme yapar. Metin, bir 
iletişim ortamı görevi gören her türden yazılı, görsel ya da sözlü ögedir. Kitapları, gazete veya dergi makalelerini, reklamları, söylevleri ve filmleri kapsar (Neuman, 2014, s. 466).

Çalışmanın araştırma sorularına yanıt bulmak amacıyla filmlerde "kare kare çözümleme" yöntemi uygulanmıştır. Bu çözümleme yöntemine göre "bir çekim serisi ya da bir film sahnesinden görüntüler üzerine kullanılan teknikler tanımlanır ve tekniklerin anlamları açıklanır (Ryan \& Lenos, 2014, S. 16).

Çalışmada başlangıçta, nokta metaforuyla bir filmin gerçekçilik bağlamında nasıl çözümlenebileceği araştırma konusu olarak belirlenmiştir. Daha sonra "filmdeki gerçekçilik, düşünümsellik, yakın çekim, ses ve senografik ögelerin" nasıl kullanıldığı gibi araştırma soruları oluşturulmuştur. Örneklem ise araştırma sorularına yanıt verecek ve veri bakımından çok veriye sahip olduğu düşünülen Yakın Çekim filmi belirlenmiştir. Son olarak ise kategoriler oluşturulmuştur.

Kategoriler oluşturulurken filmin nokta metaforıyla analizinde hangi unsurların işlevsel olduğu belirlenmiş ve bu doğrultuda gerçekçilik, düşünümsellik, yakın çekim, ses ve senografik ögeler gibi kategoriler oluşturulmuştur. Gerçekçilik kategorisinde sinemanın gerçeğe ulaşma çabasının bir uzantısı olarak nokta metaforıyla bir arada düşünülmesi yer almaktadır. Düşünümsellik kategorisi filmin kendini açık etmesi ve böylece filmin aslında gerçeğe açılan bir pencere olduğu düşüncesinden hareket edilerek inşa edilmiştir. Yakın çekim kategorisi, adından anlaşılacağı üzere teknik bir unsur olarak gerçeğe olabildiğince yaklaşmayı ifade etmektedir. Ses unsuru ise sesin kaynağının gerçekliğin bir parçası olduğunu belirmektedir. Son olarak senografik ögeler kategorisi mekânda kullanılan kapı, pencere ve perde gibi dekor unsurlarının gerçekliği saklaması ve aralandığında nasıl bir anlatım imkanı tanıdığı fikrinden oluşmaktadır.

Çalışmanın geçerlik ve güvenirliği aşamalar halinde oluşturulmaya çalışılmıştır. Nitel çalışmalarda "geçerlik, araştırma sorularının doğruluğunu; dış geçerlik, elde edilen sonuçların benzer gruplara ya da ortamlara aktarılmasından oluşurken iç geçerlik ise araştırma sonuçlarına ulaşırken izlenen sürecin çalışılan gerçekliği ortaya çıkarmadaki yeterliliği ifade eder" (LeCompte ve Goetz'den akt Yıldırım \& Şimşek, 2016, s 255). Çalışmada oluşturulan kategoriler dahilinde film, kare kare çözümleme yöntemiyle analiz edilmiştir. Kategoriler nokta metaforıyla ve her bir kategorinin kavramsal yapısıyla bir arada düşünülmüş ve bulgulara bu şekilde ulaşılmıştır. Böylece iç geçerliğe bu şekilde ulaşılmaya 
çalışılmıştır. Çalışmanın dış geçerliliğinde ise gerçekçilik, düşünümsellik, yakın çekim, ses ve senografik ögeler gibi unsurların nokta metaforıyla birlikte düşünülerek gerçekçi kuram içinde yer alan herhangi bir filme uygulanabileceği görülmüştür.

Nitel çalışmalarda "güvenirlik, araştırma sonuçlarının tekrar edilebilirliğidir. Dış güvenirlik, araştırma sonuçlarının benzer ortamlarda aynı şekilde elde edilip edilemeyeceği iken iç güvenirlik ise başka araştırmacıların aynı verileri kullanarak aynı sonuçlara ulaşıp ulaşamayacakları ile ilgilidir" (LeCompte ve Goetz'den akt Yıldırım \& Şimşek, 2016, s 255). Çalışmanın güvenirliği nokta metaforunun filmde gerçekliğe ulaşma çabası açısından nasıl bir işleve sahip olduğundan hareketle, araştırma tasarımının ayrıntılarıyla sunulmasından oluşturulmuştur. Bu amaçla çalışmanın probleminden, kavramsal çerçevesinden, örnekleminden ve yönteminden ayrıntılı ve aşamalı olarak bahsedilerek araştırma deseni oluşturulmaya çalışılmıştır.

Çalışmanın araştırma soruları şunlardır:

1. Yakın Çekim filminde gerçekçilik yaklaşımı nasıl oluşturulur?

2. Filmde yakın plan çekim yöntemi ile nokta metaforunun bir arada düşünülmesi gerçekliğe ulaşmada nasıl bir anlam içerir?

3. Filmde düşünümsellik yaklaşımı ile nokta metaforunun bir arada düşünülmesi gerçekliğe ulaşmada nasıl bir anlam içerir?

4. Filmde gerçeklik yanılsaması ile nokta metaforunun bir arada düşünülmesi gerçekliğe ulaşmada nasıl bir anlam içerir?

5. Filmde kullanılan ses unsuru ile nokta metaforunun bir arada düşünülmesi gerçekliğe ulaşmada nasıl bir anlam içerir?

6. Filmde tercih edilen senografik ögeler ile nokta metaforunun bir arada düşünülmesi gerçekliğe ulaşmada nasıl bir anlam içerir?

\section{BULGULAR VE YORUM}

Çalışmanın bu bölümünde araştırma sorularına yanıt bulmak amacıyla oluşturulan kategoriler altında filme dair bulgular verilmiş ve yorumlar yapılmıştır. 


\section{Film Hakkında}

Abbas Kiarostami'nin "gözbebeğim" (Çalkıvik, 2006) dediği Yakın Çekim filmi, gerçekliğin doğası ve parçalı yapısı dair bir filmdir. Film, İranlı yönetmen Muhsin Mahmelbaf'a duyduğu hayranlıktan dolayı kendini insanlara, Muhsin Mahmelbaf olarak tanıtan, sinema tutkunu Ali Sabzian'ın gerçek hikâyesinin kurgusal olarak yeniden çevrimidir. Sabzian kendini yönetmen olarak tanıtarak bir ailenin güvenini kazanır ve onların evlerini mekân olarak kullanarak yeni bir film yapmak ister. Ayrıca sahte Mahmelbaf olan Sabzian, aile üyelerini filminde oynamaya ikna eder. Aile, ilerleyen süreçte Sabzian'ın sahte yönetmen olduğunu anlar ve hakkında dolandırcılıktan dava açarlar. Olayı bir gazete haberinden duyan Kiarostami, aileyi ve Sabzian'ı ikna ederek yaşananların yeniden çevriminin olacağı filminde oynatır.

Film gerçek ile sahte arasındaki ilişsi üzerinden başlar. Sabzian sahte Mahmelbaf'tır ve yönetmen Mahmelbaf'ın ve ailenin gerçek dünyasına, sahte bir karakter olarak dahil olur. Ancak sahte Mahmelbaf bile olsa Sabzian'ın kendi hikâyesi gerçek bir hikâyedir. Gerçek olan Sabzian'ın yalanı, filmde bu defa kurgusal olarak yeniden üretilir. Film, onun sinema tutkusu üzerinedir. Yine Muhsin Mahmelbaf yaptığı filmlerde kurgusal bir dünya inşa eder ancak bu filmde rol aldığında gerçeği yani kendisini oynayacaktır. Aile de, sahte Mahmelbaf'ın filminde rol alarak sahtenin içinde gerçeği yaşarken bu defa Kiarostami'nin filminde rol alarak kurgusal bir dünyada gerçekten oyunculuk yaparlar.

Film, gerçekliğin kırılganlığı ve parçalı yapısı konusunda geniş bir düşünsel imkan sunar. Nokta olan bir gerçeğin nasıl çoğaltıldığı ve parçalı hale getirildiği filmde görülebilir. Yaşanan olayların sahte ve gerçek üzerine inşası, sinemaya sadece gerçeğin kırılganlığını ve parçalı yapısını sunma imkanı sunarak izleyiciyi bu konular üzerine düşünmeye davet eder. Gerçeğin kırılganlığı ve parçalı olan yapısını aşarak hakikate ulaşııma isteği, filmde kullanılan tekniklerle de sağlanmaya çalışıır.

\section{Yakın Plan Çekim Yöntemi}

Film, anlatım dili olarak kendine verilen adla bağlantılı bir şekilde 'yakın çekim'lere dayanmaktadır. Nijat Özön, close-up kavramını "omuz çekim" ve "omuz plan" olarak çevirmiş ve "bir insanı omuzlarından yukarısına dek çerçeveleyen çekim çeşidi" (2000, s. 500) olarak tanımlamıştır. Sinema kuramcıları tarafından ise close-up kavramının karşılığı olarak daha çok "yakın çekim" ifadesi kullanılmaktadır. Yakın Çekim'de de gerçeklik yakın çekim ile kurulmaya çalışılmıştır. Yakın çekim; 
izleyicinin dikkatini çekmek, özdeşleşme sağlamak, soyutlama yaratmak, düzdeğişmece sağlamak, sergileme teşhir sağlamak ve yüze dönüşme gibi etkilerde bulunmaktadır. Filmde kullanılan yakın çekim yöntemiyle izleyicinin dikkatini çekme bulunmaktadır. Ancak filmde özdeşleşme sağlanmamaktadır. Çünkü izleyici açı-karşı açı çekimlerle dikilmemektedir. Filmi izlemeye başlayan izleyici, çerçeveyi keşfettiğinde başlangıçtaki haz yerini bir eksikliğe bırakmaktadır. İzleyici "olmayan birinin" bakış açısında olayları takip etmektedir. Ancak "açı-karşı açı çekimiyle bu yırtık dikilir ve izleyici başlangıçtaki o hazza yeniden ulaşır" (Dayan, 2011, s. 89). Yakın Çekim'de açı-karşı açı çekimi unsuru kullanıımamıştır.

Yine yakın çekimin anlatım olanaklarından bir diğeri ise Deleuze ve Guattari'nin (Deleuze \& Guattari, 2005, s. 175) ifadesiyle yakın çekimde gösterilenin "yüze dönüştüğü" gerçeğidir. Yakın Çekim'de karakterlerin yakın çekimlerinin kullanıldığı görülmektedir. Filmin ana karakteri Sabzian'ın yakın çekimlerle gösterilerek etki yaratıldı̆ı söylenebilir.

Filmde çekim tekniği olarak kullanılan yakın çekim yöntemi, bir yanıyla gerçeğe yaklaşım anlamı içerse de diğer yanıyla ekran dışında bıraktıklarıyla da önem taşımaktadır. Böylece "alan-dışı bir belirsizlik, hatta bir eylem yeri haline gelir ve ona dramatik bir güç kazandııı" (Bonitzer, 2013, s. 16). Gerçeğin çoklu yapısını işaret ederek ekran sınırları içerinde gösterilen görüntüler dışında da gerçekliğin parçalarının olabileceğine dikkat çekilir. Filmde de yakın çekimlerin kullanıldığı planlarda aynı zamanda alan-dışının da dramatik bir potansiyeli olduğu görülmektedir.

Yakın çekimle birlikte büyüyen ekran-dışının varlığı gerçekliğin kırılganlı̆̆ını artırmakta ve "temsilde bir huzursuzluğa, bir bölünmeye" neden olmaktadır (Bonitzer, 2013, s. 17). Bonitzer bu konuda şu şekilde devam eder: "Off-uzay sadece ekranın gösterdiklerine ek bir gerçeklik vermek için kullanılır; ya da tersine, sinematografik uzayın tamamlanmamışlığının, yarıklı̆ının, bölünmmüşlüğ̈nün altını çizmek için off-uzay vurgulanır. Bu son durumda sinema, klasik sinema denen süreklilik snemasınınkinden çok farklı bir oyuna açılmış olur" $(2013$, s. 22).

Film yapım sürecine, yönetmen ve oyuncuya, izleyicinin konumuna ilişkin irdelemelerde bulunan Yakın Çekim aynı zamanda sinema ve gerçeklik ilişkisine, gerçekliğin çok parçalı yapısına, hakiki ve sahte ilişkisine de yakın çekim yapmaktadır. 


\section{Sinema ve Gerçeklik Yanılsamasının ve Düşünümsellik Yaklaşımı}

Yakın Çekim'de senaryo, bir gazete haberinden yola çıkılarak oluşturulmuştur. Parçaların, ayrıntıların önemli olduğu gerçeğinden hareketle başkasının bakmadığı yöne bakarak, gerçekliğin oradan oluşturulmasına başlanmıştır. Görünen ardındaki görünmeyene odaklanma amaçlanır.

Film, fotoğraf karesi misali bir gazete haberinden yola çıkılarak yapılmıştır. Susan Sontag Fotoğraf Üzerine $(2011$, s. 3) adlı çalışmasında bir şeyin fotoğrafını çekmenin "fotoğraflanmış olan o şeyi ele geçirmek..., insanları soyutlamaya alıştırmak ve fotoğraflanmış görüntülerin dünyayla ilgili tespitler olmaktan ziyade, dünyanın parçaları" haline getirmek anlamına geldiğini ifade etmektedir. Sontag ayrıca fotoğrafların kanıt özelliği taşıdığını ekler $(2011$, s. 5). Bu anlamda Yakın Çekim de bir fotoğraf karesi misali bir gazete haberinden hareketle yapılır. Ayrıca gazete haberinde fotoğraflara da yer verilir.

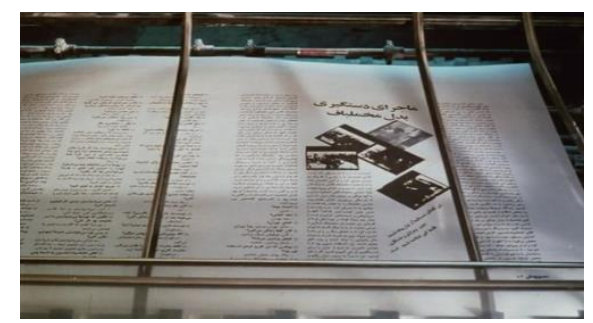

Fotoğraf 1 Gazete Haberi ve Fotoğraflar

Berger (2015, s. 36 - 37) bir fotoğrafın biçimsel bir özellikten öte zamanla ilgili bir etkileşimi içerdiğinden hakiki içeriği gösteremeyeceğini belirtir ve şöyle devam eder: "Fotoğraf görülmüş olanı kaydederken, daima ve doğası gereği, görünmeyene de işaret eder. Sürekliliği olan bir bütünün içinden aldığı bir anı yalıtır ve sunar. Fotoğraftaki görüntülerin doğal dünyaya göndemesi, hiçbir zaman doğrudan değil, muadilleri aracılığıyla olur."

Fotoğraf "mevcut olan gösterdiği kadar olmayanı da gösteriyorsa" başarılı sayılır ve bu başarı "gösterdiği şey gösterilmemiş olanı akla getirir(diği)" müddetçe var olabilir (Berger, 2015, s. 38-39). Bu bakımdan bir fotoğrafın gerçeğin temsili olamayacağını ve gerçeğin çoklu parçasından sadece bir parça olduğunu bilmek gerekir. Bu bakımdan filmde de bir fotoğraf misali bir anın gerçeğini alan gazete haberi ile birlikte gerçeğin çoklu yapısına ulaşılma amaçlanmaktadır. Ayrıca filmin açıışında, olayın nasıl gazete haberine dönüştüğü anlatııır. Gazeteci Farazmand, iki askerle birlikte, sahte Mahmelbaf olan Sabzian'ın haberini yapmak için Ahankhahlar'a gider. "Yılın haberini yapacağını" söyleyen Farazmand oldukça 
mutludur. Sabzian'ın fotoğraflarını çeker ve gerçeği kendince yeniden kurgular. Böylece gerçeklik gazete haberine dönüşme sürecinde de yeniden üretilir. Haber ve fotoğraflar gazetede "Sahte Mahmelbaf Tutuklandı" şeklinde yayınlanır. Daha sonra mağdur aile, gazetecinin "ben olmasam gerçekler ortaya çıkmazdı" şeklindeki sözlerine tepki gösterirler ve baba Ahankhah "neler olduğunun farkındaydım sadece rol yapıyordu" diye kendini savunur.

Sinema tarihinde fotoğrafın, gerçekliğin bir nüvesi olarak kullanıldığı başka filmler de vardır. Gerçeğin kırılganlığı ve çok parçalı yapısı üzerinden Cinayeti Gördüm (Blow-Up, Antonioni, 1966) filmini ele alan Gültekin (2018) çalışmasında filmin, gerçeğin bozulan, yarılan, değişen kısaca kırılganlığını ortaya koyan göstergelerle dolu olduğunu vurgular. Bu anlamda Cinayeti Gördüm filminde de gerçek, bir nokta misali bir fotoğraftan yayııır. Filmin kahramanı Thomas, parkta çektiği fotoğrafları bir araya getirerek anlam oluşturmuş ve bir cinayete tanık olduğunu anlamıştır. Cinayeti Gördüm filminde "mercek, filmin adını almasını sağlayan temel nesne konumundadır. "Blow-Up", İngilizce "mercekle resimleri büyütmek/genişletmek" anlamında da kullanılan bir kelimedir. Filmde mercek aracılığıyla gerçeğin derinliğine inmeyi başaran Thomas, seyirciye de bu nesne aracılığıyla gerçeğin kırılgan yapısına dair yorum alanı bırakır" (Gültekin, 2018, s. 1720).

Türk sinemasında da bir fotoğraf karesi üzerinden kurulan anlatılar mevcuttur. Metin Erksan Sevmek Zamanı (1965) filminde bir fotoğraftaki yüze, surete aşık olan Halil'in yüzün sahibiyle karşılaşmasını ele alır. Gizli Yüz (Ömer Kavur, 1991) filminde ise bir kadın, hayallerinde taşıdığı ve günün birinde kavuşmayı umduğu bir yüzü arar. Bir fotoğrafçıdan farklı mekânlarda fotoğraflar çekmesini ister ve sonunda aradığı yüzü bir fotoğraf karesinde bulur ve bu yüzün sahibini bulmak için arayışa koyulur. Ömer Kavur, Melekler Evi (2000) filminde de yine fotoğraf üzerinden bir anlatı kurar. Filmde muhabir olan Ahmet'in çektiği fotoğraflarla bir cinayete tanık olması anlatılır.

Gerçekliğin tek bir haberden yola çıkılarak oluşturulması, akla Kuran'ın ihtivasına dair izahları getirmektedir. Şöyle ki; "başlangıçta, alimler, Fatiha Suresi'nin Kuran'ın tamamını oluşturduğunu, sonra üç îhlas Suresi'nin de Kuran'ın tamamına denk geldiğini söylemişlerdir. Alimler açıklamalarını daha ileri götürerek, besmelenin de Kuran'ın tamamına denk geleceğini söylemişler ve aslında besmeledeki "b" harfinin Kuran'ı temsil ettiğini eklemişlerdir. Son olarak geldikleri nokta "b" harfinin altındaki "." (noktanın) Kuran'ı temsil ettiğini söylemeleri olmuştur". Yine Hz. Ali'ye isnat edilen bir sözde "ilim bir nokta idi, onu 
cahiller çoğalttı" ifadesi kullanılmaktadır. Hakikatin, gerçeğin bir nokta olduğu ve diğer görünen şeylerin bu noktadan hareketle türetildiği söylenmektedir (Tabakoğlu \& Maden, 2019).

Yakın Çekim filminde de bir nokta olan gerçek, ilk olarak gazete haberi ve fotoğraflarıyla çoğaltııır. Gerçeklik kırılgan ve parçalı hale getirilir. Bu anlamda Yakın Çekim'de her şey nokta misali bir gerçekten yola çıkılarak oluşturulmuştur. 0 nokta ki, aslında içinde daha sonra gösterilecek olanları taşımaktadır. Bir noktadan hareketle bir cümle yazmaya başlanır. Gerçeklik veya hakikat o nokta mıdır? Noktayı çoğaltma isteği gerçeği bilme tutkusu mudur? Gerçek ile sahtesi arasındaki ilişki nedir? Gerçekliğin bu çoklu yapısı hakikate ulaşmada arada bir perde midir? Tüm bunlar sinema aracılı̆̆ıyla nasıl oluşturulmuştur? Yakın Çekim'de bu soruların cevabı nelerdir?

Bonitzer (2013, s. 12) filmde ekranın sunduğu gerçekliğin, hiçbir zaman hakiki bir tatmin sağlamayacağını ancak şaşırtabileceğini, korkutabileceğini ifade ederek şöylr devam etmektedir; "izleyici, ekranda gösterilenin hileli olduğunu bile bile olayların gerçekliğine inanmak istemektedir. Sinema gerçeklik düzeyinde, bir inkarla geçiştirilmesi gereken bir çeşit shize sunmaktadır".

Gerçekliğin bir bütün olamayacağı ve gerçekliğin parçalı yapısı Yakın Çekim'de ele alınan konuların başında gelmektedir. Gerçekliğin parçalı yapısı kısmi görme ve kilitlenmiş görme kavramlarını akla getirmektedir. Ayrıca sinemada görsel alanın yanında bir de kör alan mevcuttur ve "görme kısmiyse düşman (gerçeklik) gücül olarak her yerdedir" (Bonitzer, 2011, s. 70).

Kısmi görmenin, kameranın görmesi, çerçevelemeler ve kameranın konumları anlamına geldiğini söyleyen Bonitzer şunları eklemektedir; "Andre Bazin'den beri biliyoruz ki sinema ekranı, bir tablo çerçevesi gibi değil 'olayın sadece bir parçasını gösteren bir kaş' gibi iş görür. Görsel alana her zaman bir de kör alan eklenir, görme her zaman taraf tutucu olmasa bile her zaman kısmidir. Sinema ekranındaki nesneler şimdi burada az sonra oradadır" (2011, s. 84). Kilitlenmiş görme ise "kısmi görmeye seyirciler açısından ekranın ve projeksiyonun düzenine uygun olarak oluşturulur. Kamera görüntüler arasından seçim yaparken izleyici ekranda yansıyan görüntüyü seyretmek ya da seyretmemek arasında tercih yapmak zorundadır" (Bonitzer, 2011, s. 85).

Yakın Çekim bir gazete haberinden yola çıkılarak yapılmıştır. Kiarostami, gerçeklik parçalarını ortaya çıkarmak için önce, gazeteci Farazmand'ı mağdur aile Ahankhahlar'a götüren taksi şoförüne, 
dağınık olan çiçekleri toplattırır. Filmin sonunda sahte Mahmelbaf'ın (Sabzian) elinde bir demet çiçekle gerçekliğin bir araya getirilmeye çalışıldığı görülür. Diğer taraftan yönetmen Kiarostami de gerçekliğin peşine düşerek ve çok parçalı yapısını hatırlatarak polisle, mağdur aileyle ve Sabzian ile görüşür. Ancak Kiarostami de yaptığı şeyin gerçekliğin yeniden üretimi olduğunu bilmektedir.

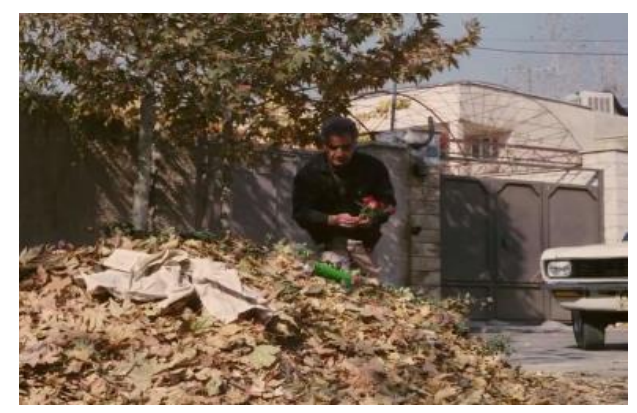

Fotoğraf 2 Gerçekliğin Parçaları Toplanıyor

Cezaevinde Sabzian ve onunla görüşmeye giden Kiarostami, gerçekliğin çok parçalı yapısı hatırlatılır gibi çerçeveler arasında görünmektedir. Görüntü yavaşça yaklaşır ve yakın çekimle Sabzian içinde bulunduğu durumu, Deleuze ve Guattari'nin $(2005$, s. 190) probe-heads açıklamalarında olduğu gibi "yakın çekimde kafa adeta sondaja uğrayarak" içindeki gerçekliği ortaya çıkarmaktadır. Sabzian, Kiarostami'den yaşananları filme çekmesini ister. "Yaptığım dışarıdan dolandırıcılık gibi gözüküyor ama tüm olan bu değil, sinema heveslisiyim" diyen Sabzian gerçekliğin önündeki perdenin aralanmasını ister. "Zahire aldanma batına bak" demek ister.

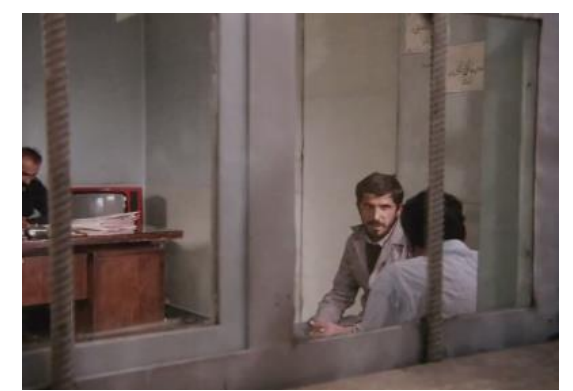

Fotoğraf 3 Gerçekliğin Çok Parçalı Yapısı

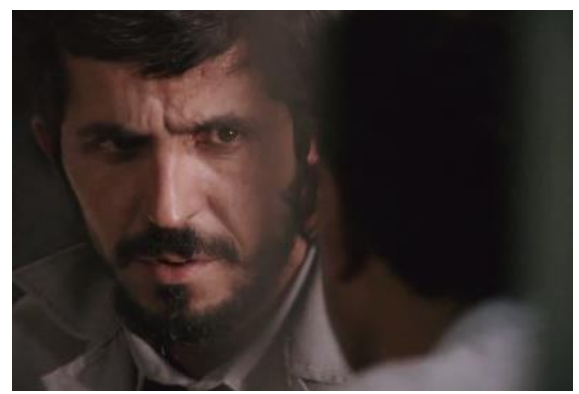

Fotoğraf 4 Gerçeğe Ulaşma Çabası

Aslında Sabzian yaptıklarından dolayı "çile çekmeye" başlar. Farsça'da "çile" kelimesi "çihil" (kırk) kelimesinden gelmektedir. Tasavvuf ehli "kırk günlük halvete" çekilerek tenha ve sakin bir yerde kendiyle yüzleşir (Cebecioğlu, 2005, s. 55). Sabzian'ın Ahankhahlar'a geldiği ilk gün ve gerçek Mahmelbaf ile birlikte elinde çiçekle geldiği son gün arasında kırk gün vardır; filmin sonunda Mahmelbaf Sabzian'a sorar 
"buraya ilk ne zaman geldin" Sabzian gözyaşları içinde "kırk gün önce" der. Çile tamamlanmıştır. Çile çekmeye sebep, sadece sahte Mahmelbaf olarak birilerini aldatmak mıdır? Belki; ama filmin derin anlatım katmanlarına girince yeterli olmuyor. Peki nedir bu çileye sebep?

Hüseyin Sabzian bir sinema tutkunudur. Sabzian kendisini Ahankhah ailesine ünlü yönetmen Muhsin Mahmelbaf olarak tanıtır. Kiarostami mahkemede, Sabzian'dan duruşmanın kayıt altına alınması için izin istemektedir. Sabzian "tabi" der "benim seyircimsiniz, benim sanat, film tutkumu izliyorsunuz".

Bu arada şunu da ifade etmek gerekir ki filmde modernist sanat unsurlarına da yer verilmektedir. Kovacs (2010, s. 216) modernist sinemanın üç özelliğinden bahsetmektedir; soyutlama, öznellik ve özdüşünümsellik. "Soyutlama, biçimin doğayı ya da gerçekliği temsil etmenin geleneksel yollarına değil, ama gerçekliğin ya da doğanın temel oluşturucu ilkelerinin esaslı bir özeti olarak görülen bir kavramsal yapıya ya da sisteme gönderme yapma anlamına gelir. Modem biçimin öznelliği, bu kavramsal sistemlerin genellikle yaratııının (auteur) şeylere bakmanın yeni bir sanatsal yolu olarak kabul edilmesi gereken girişimi biçiminde sunulması anlamına gelir. Modem biçimlerdeki kendini yansıtma, biçimin bu girişimin izleyici tarafından da anlaşılacağı bir tarzda oluşturulması anlamına gelir. Başka bir deyişle, sanat yapıtı kendisini sanatsal bir gelenekten ayrılan bir sanat yapıtı olarak gösterir."

Yakın Çekim'de sinemada üretim süreci ele alındığından soyutlama ve yönetmenin izini taşıdığından özdüşünümselliğe işaret etmektedir. Ayrıca filmin üretim süreci (teknik sistemin gösterilmesi gibi) devamlı olarak gösterilmekte böylece izleyiciye film izlediği hatırlatılmaktadır. Böyle bir durumda Peter Wollen'in (2013) işaret ettiği öne çıkma mevcuttur.

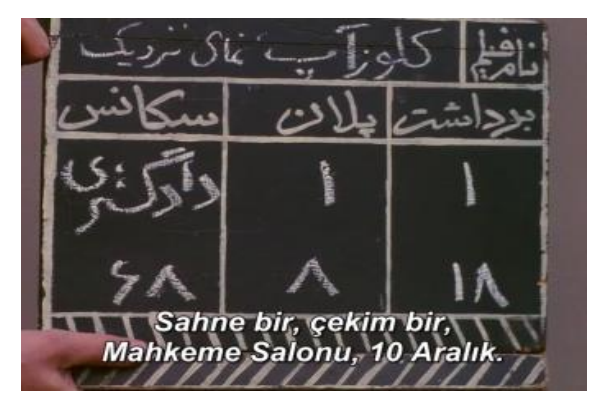

Fotoğraf 5 Sürekli Olarak Gösterilenin Film Olduğu Hatırlatılıyor

Yakın Çekim'de olaylar iç odaklanma ile anlatılmaktadır. Anlatııı kahramanın kimliğine bürünmüş gibi kişinin yerine, kahramanın düşündüğü, hissettiği ve yaptığı şeyleri anlatır. Kişiler ve olaylar bir kişinin 
gözünden anlatıldığından sınırlı bir bakış açısı vardır. Okurun, izleyicinin bilgisi anlatıcı kadardır. i̇ç odaklayım birinci kişi adıyla anlatı içermez (Kıran \& Kıran, 2000). Filmde olaylar Sabzian aracılığıyla üçüncü kişi adıyla anlatılmaktadır.

Sabzian duruşmada, "kimseyi dolandırmaya çalışmadım bunların hepsi sinema aşkımdan dolayı oldu, küçükken sinemaya giderdim arkadaşlarla film çevirme oyunları oynadık, imkanım olmadığı için sanatsal heveslerimden vazgeçtim, takıntı haline geldi" demektedir. Başlangıçta Sabzian, sinema tutkusundan dolayı böyle bir yalana başvurmuştur. Ancak zaman geçtikçe, ailenin "yönetmen olarak, star olarak" ayrıcalıkı konumundan dolayı ona gösterdiği saygı ve ilgi onun rolünü sahiplenmesine neden olmuştur. Sabzian artık tutkusunun peşinden gitmemektedir, tutkusunu sömürmektedir. Sabzian'ın tutkusunu sömürerek gerçeği incitmeye başladığı söylenebilir. Filmin sonunda Sabzian'ın dökmüş olduğu göz yaşları bundan dolayıdır.

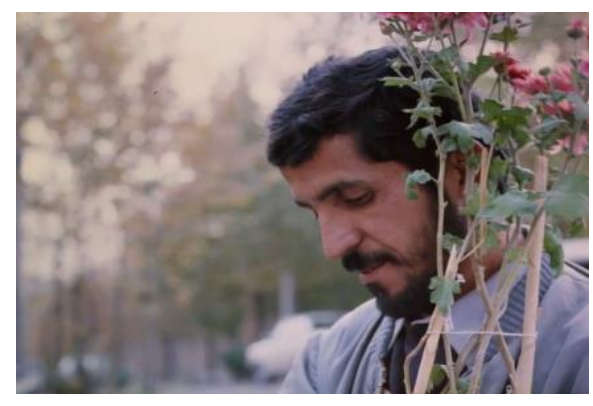

Fotoğraf 6 Çile Tamamlandı

Filmin sonunda gerçek Mahmelbaf ile sahtesinin motosiklette arka arkaya görüntüsü, bir nokta misali, gerçeğin nokta olduğu, ondan türeyen diğer her şeyin ise onun bir parçası olduğunu akla getirmektedir. Ayrıca sahtenin her zaman gerçeğin ardından gideceği, çokluk parçalarının kaynağı olarak noktanın başlangıç olacağı hatırlatılmaktadır.

\section{Ses Unsuru}

Gerçekliğin parçalı ve kırılgan yapısının kendisini gösterdiği bir başka unsur da sestir. Sinemada gerçekliği oluşturmaya çalışırken görüntünün yanında ses de kullanılmaktadır. Ses, gerçekliği yansıtmada ve oluşturmada sinema için etkili bir araçtır. Filmde gerçekliğin her bir parçasının eşit önemi kendisini ses ve görüntü ilişkisinde de göstermektedir. 
Ses unsurunda kaynağı bilinen ya da bilinmeyan, ekranda gözüken ya da ekran dışında olan bir kaynaktan gelen sesin, kendine göre anlamları bulunmaktadır. Ekran dışı alanın ekran üzerindeki etkisi, kendisini görüntüde olduğu gibi ses unsurunda da göstermektedir. Bonitzer (2013, s. 27-29) "ses görüntüyle bağlarını koparıp ona dışarıdan musallat olduğunda, görüntüyü ve dolayısıyla görüntünün yansıttığı gerçek'i avucunun içine alır" ifadesini kullanır ve şöyle devam eder "dış sesin bir iktidarı, mutlak olarak başka bir yerden gelip görüntüye ve onun yansıttığına sahip olma iktidarını temsil eder". Aynı şekilde Mladen Dolar (2013, s. 64-65) da, kaynağı görülemeyen (akuzmatik) sesin, "ilahi bir nitelik taşıdığını, dışarıdan görüntüye hakim olduğunu" söylemektedir. Alfred Hitchcock'un Sapık(Psycho, 1960) filminde annenin sesinin görüntü üzerindeki etkisi buna örnek verilebilir.

Yakın Çekim'de kaynağı belli olmayan ses niteliğine sahip ses unsuru yoktur. Dış ses vardır ancak bu sesin kaynağı bellidir. Filmde sürekli olarak yönetmen Kiarostami'nin sesi, dış ses olarak duyulmaktadır. Burada dış sesin görüntü üzerindeki iktidarından (Bonitzer, 2013, s. 29) yani yönetmenin varlığının her an hissedilmesinden ve Metz' in (1992, s. 314) deyişiyle "biz, ses hakkında konuştuğumuzda aslında sesin kaynağına ait görsel imgeyi düşünürüz" durumu yaşanmaktadır. "Ses bedene iliştirildiğinde, kadir-i mutlak karizmatik karakterini kaybeder, sıradan hale gelir, yeri bellirlenir belirlenmez, cazibesi ve gücünü kaybeder" (Dolar, 2013, s. 70). Yönetmenin gerçekliği yeniden kurarken ekranda kendi iktidarını hissettirdiği söylenebilir. Yine filmde yönetmen Kiarostami'nin sesi çoğu zaman özellikle de mahkeme salonunda ekran dışından gelir ve sesin ekran üzerinde oluşturduğu bir "otorite ve artı anlama" (Dolar, 2013, s. 65) neden olduğu söylenebilir.

Akuzmatik yani kaynağı görülemeyen ses "radyo, gramofon, kasetçalar, telefon gibi yeni araçların ortaya çıkmasıyla birlikte yaygınlaşmış" ve bütün bu araçlar "akuzmatik doğayı" paylaşır hale gelmişlerdir (Dolar, 2013, s. 66). Filmde gazeteci Farazmand'ın, Sabzian'ı tutuklattıktan sonra kapı kapı dolaşarak ses kayıt cihazı araması, akuzmatik sesin varlığına ve gücüne bir gönderme olarak düşünülebilir. Sabzian'ı tutuklattıktan sonra kapı kapı dolaşarak ses kayıt cihazı araması görüntünün tek başına yeterli olmadığını ses ögesinin de gerçeklik üzerindeki etkisini göstermektedir.

Filmin sonunda, Muhsin Mahmelbaf'ın motosikletle cezaevi önüne gelip Sabzian'ı karşıladığı sahnede, gerçekliğin kırılganlığı ve parçalı yapısına göndermede bulunan diyaloglar vardır. Uygun görüntüyü alamayan ekip, "bu çekimi tekrar yapamaya(caklarını)" belirterek hem gerçekliğin kırılganlığına 
hem de parçalı yapısına göndermede bulunurlar. Filmin sonunda, sahte Mahmelbaf ve gerçek Mahmelbaf'ın arasında geçen diyalogların kesintiyle takibi yine gerçekliğin inşasında ses ögesinin önemini göstermektedir. Bir araba içerisinde sahte Mahmelbaf olan Sabzian ile Muhsin Mahmelbaf'ın buluşmasını görüntüleyen Kiarostami ve ekibi, sesin kesik kesik geldiğini farkederler. Kurgusal olsa da olayların yansıtılması ses ve görüntünün tam olarak alınmasına bağııdır.

\section{Senografik Unsurlar}

Yakın Çekim'de senografik öge olarak sıklıkla kapı, pencere ve perde gibi unsurların kullanıldığı görülmektedir. Kapı, pencere, perde, duvar ve büyük beton bloklar motif olarak kullanılmıştır. Böylece bu unsurlar gerçeklik önündeki engel, gerçekliğin çoklu yapısı ve gerçekliğe açılan bakış olarak izlekler oluşturmaktadır. David Bordwell ve Kristin Thompson'a (2011, s. 68) göre motif, "biçimsel yinelemeler" olup, "filmde yinelenen ögeler" olarak adlandırılmaktadır. İzlek ise ana konuyu oluşturmaktadır. Motifler somuttur ve birleşerek soyut olan izleği oluşturmaktadır.

Filmin başlangıcında gazeteci Farazmand, taksici ve iki askerle birlikte sahte Mahmelbaf olan Sabzian'ın haberini yapmak ve tutuklamak için Ahankhahlar'ın evine giderken, evin de bulunduğu Lavizan semtini çevreleyen büyük beton bloklarla karşılaşırlar. Film aslında açılışından itibaren duvar ve engel görüntüleriyle kaplıdır; bu da gerçeğin önündeki engeller olarak okunabilir. Yine mağdur ailenin evi, çıkmaz bir sokaktadır. Gazetecinin "böyle bir haberin çıkmaz sokaktan çıkması çok ilginç" şeklinde ifadesi de gerçeği ortaya çıkarmanın o kadar da kolay olmadığı düşüncesini akla getirir.

Fetiş bir nesne olarak metin (Barthes, 2007, s. 114) ile beraber, görüntü içindeki kapı da bir plandan ötekine geçiş sağlamanın yanında görme arzusu doğurur ve yönlendirme yapar. Simmel (2006, s. 172) kapının, insanların yaşadıkları mekân ve onun dışında kalan her şey arasında ilişki kurduğundan içerisi ve dışarısı arasında ayrımı ortaya çıkaracağını, içeri ile dışarısı arasında ayırma ve bağlamayı sağlayacağını ifade etmektedir. Pencere ise içeri ile dışarısı arasında ilişkiyi sağlamakta (Simmel, 2006, s. 173) aynı zamanda gerçekliğin çoklu yapısını akla getirmektedir.

Kapı, içeriyle dışarı arasında bir sınır çizmektedir. Kapı bir yanıyla bilinmezliğe neden lurken ve gerçeği perdelerden diğer yanıyla aralandığında gerçeğe ulaşıımayı mümkün kılan bir özellik taşımaktadır. "Kapıların sinemadaki özgül rolü, görme arzusunu harekete geçirmek ve yönlendirmektir" ve "kapı 
hakikate, kötülüğe giden yolu kapayan - aynı zamanda da oraya açılan - bir fetiştir" (Bonitzer, 2013, s. 88-89).

Yakın Çekim'de bir diğer senografik öge ise perdedir. Batını saklayan zahir olarak perde gerçeklik önündeki engel işlevi görmektedir. Sahte Mahmelbaf 'görüntü aldatıcı olabilir yüzümüzü örten maskelerin esirleriyiz. Eğer maskelerimizden kurtulursak, gerçeğin güzelliği bizim olacak' demektedir. Filmde birçok defa karakterler pencereden dışarıya bakarlar ama hepsinde perde kapalıdır. Gerçeğin ortaya çıktığı ve Sabzian'ın yakalandığı, ardından polisler tarafından evden götürüldüğü sahnede ise Ahankhahlar'a misafir olarak gelen Muhsini tarafından perde aralanır. Ferahmend (2007, s. 130) Kiarostami'nin filmlerinde var olan bir üslubun, "varlığıyla seyirciyi filmin diğer karakterleriyle eşit bir paylaşıma ve müşfik bir ilişkiye girmekte alıkoymaktan aracı bir karakterin filme eklemlenmesi" olarak kendini gösterdiğini ifade etmektedir. Yakın Çekim'de bu karakter Muhsini'dir. Onun eliyle perde aralanarak gerçekliğin görünmesi sağlanmaktadır.

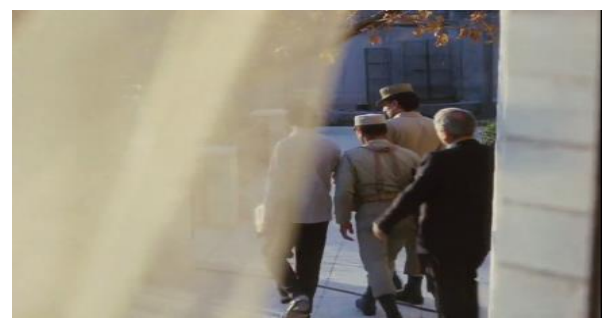

Fotoğraf 7 Gerçeğe Perde Aralanıyor

Filmde dikkat çeken bir diğer unsur ise evdir. Filmde gösterilen evler, yüksek ve güvenlikli duvarlarla çevrilmiş, kapalı kapılar ardında sırlanmışlardır. "Ev, bir gevşeme ve bir mahremiyet uzamı olarak, mahremiyeti yoğunlaştırması ve koruması gereken bir uzam olarak" değer görmektedir (Bachelard , 2008, s. 92). Bir mahremiyet alanı olarak evde insanlar, sırlarını ve hayallerini biriktirirler. Bu mahrem alan, gelişi güzel herkese açılmaz. Filmde Ahankhahlar'ın evine ancak, çok sevdikleri sinema sanatının, bir temsilcisi olarak Sabzian girebilmiştir. Evlerinin tüm odalarını ona açmışlardır.

\section{SONUÇ}

Yakın Çekim filminde Abbas Kiarostami, nokta olan bir gerçeğin peşine düşmektedir. Kiarostami, bu gerçeğin üzerini örten perdelerin aralanmasını istemektedir. Gerçekçi film kuramcıları, gerçeğin kırılgan, parçalı ve çok boyutlu olduğunu, sinemanın bu gerçekliğin ortaya çıkarılmasında etkin bir sanat 
olduğunu ifade ederler. Diğer taraftan gerçeğin bir nüvesi olarak nokta da gerçeğe ulaşma girişiminde önem taşımaktadır. Bu bakımdan çalışmada, sinemada gerçekçilik yaklaşımı ve nokta metaforunun bir arada düşünülmesinin bir filmin analizinde nasıl bir potansiyel taşıdığı merakı üzerinden hareket edilmiştir.

Çalışma kapsamında örneklem olarak belirlenen Yakın Çekim filminde gerçeğin ortaya çıkarılması için yakın çekim, diyalog, ses ve çeşitli senografik unsurlardan yararlanılmıştır. Filmde nokta metaforunun bir uzantısı olarak gerçeğe ulaşma adına yakın plan çekim yönteminin sıklıkla kullanıldığı görülmüştür. Yakın çekim yöntemi kullanılırken bir taraftan ekranda belirli bir alana odaklanma yaşanırken aynı zamanda ekran dışının da ekran üzerindeki etkisi de olduğu görülmüştür.

Gerçeğin kırılganlığı, parçalı yapısı, kurmaca ve gerçek arasındaki ince sınırda ilerleyen filmde gerçeklik yanılsaması da yer almaktadır. Başlangıçta gerçek bir olayın haberleştirilmesi ve fotoğraflarının çekilmesiyle ifade edilmeye çalışılan gerçeklik, bu defa yönetmen eliyle olayın gerçek kahramanlarının rol aldığı filmde yeniden inşa edilir. Kurmaca ve gerçek arasındaki sınırda ilerleyen film, bu anlamda gerçeklik yanılsaması içerir.

Ses unsuru da yine gerçekliği tamamlayan bir öge olarak kullanılmıştır. Gerçekliğin kırılganlığı ve parçalı yapısını ortaya koyan ses unsuru filmde, sürekli olarak vurgulanmaktadır. Ekran dışı sesin görüntü üzerindeki etkisi ve onu etkilemesi sık sık görülmüştür.

Filmdeki senografik ögeler de yine gerçekliğin kırılganlığı, parçalı ve çok boyutlu yapısı konusunda ayrıntılı okumalara imkan tanımıştır. Senografik ögeler, gerçeğe ulaşma adına engelleri ifade ettiği ve bu engellerin ortadan kaldırılması için işlevsel olarak kullanılabildiği sonucu çıkarılmıştır.

Son olarak tüm bu unsurların, nokta metaforu, zahir-batın ve vahdet-kesret ayrımı ile bir arada düşünüldüğünde gerçekliğin kırılganlığı, parçalı yapısı ve çabası gerçeğe ulaşma adına işlevsel bir rolü olduğu görülmüştür.

\section{EXTENDED ABSTRACT}

The realism and formalism approach constitutes an important aspect of theoretical discussions since the beginning of cinema. For the theorists who advocate the realism approach, cinema has wide possibilities and potential in revealing the truth. Examining the multilayered structure of reality and 
reaching the truth is also a feature of mystical thought. In this sense, a link can be established between the realistic approach in cinema and the approach of Sufism to reality. Another concept important for the study is the point metaphor. The point metaphor is thought to have a functional aspect in terms of the uniqueness and multiplicity of reality to remain hidden or reveal. At the same time, the point metaphor is important in analyzing the film to be analyzed in the study. The analysis of cinematographic elements such as the use of "sound and scenographic elements" along with "close-up, reflexivity, an illusion of reality", which are important elements of the realistic approach, with the point metaphor constitutes the analysis part of the study. Close-Up (1990) directed by Abbas Kiarostami was analyzed in terms of cinema and illusion of reality, reflexivity, sound element, and scenographic elements. Kiarostami reminds the Iranian people of a different view of the world and the questioning of reality with his films. Kiarostami treats the world from a different aspect, within the framework of the nature and versatility of reality, which cannot be noticed from the ordinary point of view. Kiarostami makes his audience re-question the world in the form of questioning reality. Kiarostami can be said to remind us that only the reflections of the truth can be shown with films and art in general. When the subject is approached from the perspective of Sufism in the relationship between cinema and Sufism, it is seen that the concepts of "zahir-batin" and "unity-sacrament" are important. Especially in terms of the limitation of the study in a sense, only the "point metaphor" used in Sufism and cinema were considered together. From this point of view, it is seen that cinema and Sufism can be considered together in terms of approaching the concepts of reality and truth. This study will be carried out in a scanning model to interpret the findings obtained by making determinations about an existing situation. The scanning model refers to revealing an existing situation. Qualitative content analysis was used as the data analysis method in the study. Qualitative content analysis is the "technique of collecting and analyzing text content". In this study, firstly, the analysis of a film in the context of realism was determined with the point metaphor as a research subject. Then, how to use "realism, reflexivity, close-up, sound and scenographic elements in the film" as research questions were formed. As a sample, the Close-up movie, which is thought to have the most data in terms of data to answer research questions, was determined. Later, the categories and scale were clarified. In Close-Up, director Abbas Kiarostami pursues a truth that is the point. Kiarostami demands that the curtains covering this reality be opened. Realistic film theorists state that reality is multidimensional and must be revealed. Close-up, dialogue, sound, and various 
scenographic elements are used to reveal the truth in the film. The reality was tried to be established with a close-up in Close-up. Studying the filmmaking process, the director and the actor, the position of the audience, Close-up also takes a close-up of the relationship between cinema and reality, the multipart structure of reality, and the relationship between real and fake. In Close-Up, the scenario was created based on a newspaper article. Based on the fact that the parts and the details are important, the reality has begun to be created from there, looking at the direction that someone else is not looking at. Another striking element in the movie is the concept of home. The houses shown in the movie are glazed behind closed doors surrounded by high and secure walls. The "home is valued as a space of relaxation and privacy, as a space that should intensify and protect privacy". As a privacy space, people at home collect their secrets and dreams. And this private area is not open to everybody randomly. In the film, only Sabzian entered the house of Ahankhahlar as a representative of the cinema they love so much. They opened all the rooms of their house to him. Another noteworthy element in Close-up is the use of sound. The equal importance of each part of reality in the film shows itself in the relationship between sound and image. It is seen that door, window, and curtain elements are frequently used as scenographic elements in Close-Up. By using a door, window, and curtain as a motif; The obstacle to reality creates themes as the multiple structures of reality and the view that opens to reality.

\section{KAYNAKÇA}

Aktaş, C. (2005). Şark'ın şiiri: Irran sineması. İstanbul: Kapı yayınları.

Andrew, J. D. (2010). Büyük sinema kuramları. (Z. Atam, Çev.) İstanbul: Doruk yayınları.

Bachelard, G. (2008). Uzamın poetikası. (A. Tümertekin, Çev.) İstanbul: Itthaki Yayınları.

Barthes, R. (2007). Yazı üzerine çeşitlemeler: Metnin hazzı. (Ş. Demirkol, Çev.) İstanbul: Yapı Kredi Yayınları. Bazin, A. (1995). Çağdas sinemanın sorunları. (N. Özön, Çev.) Ankara: Bilgi yayınları.

Bazin, A. (2007). Sinema nedir? (i. Şener, Çev.) İstanbul: İzdüşüm yayınları.

Berger, J. (2015). Bir Fotoğrafı Anlamak. (B. Eyüboğlu, Çev.) İstanbul: Metis Yayınları.

Bonitzer, P. (2011). Kör alan ve dekadrajlar. (i. Yaşar, Çev.) İstanbul: Metis Yayıncılık.

Bonitzer, P. (2013). Bakış ve ses. (i. Yaşar, Çev.) İstanbul: Metis Yayıncılık.

Bordwell, D., \& Thompson, K. (2011). Film sanatı. (E. Yılmaz , \& S. Onat, Çev.) Ankara: De-Ki Yayınevi.

Cebecioğlu, E. (2005). Tasavvuf terimleri ve deyimleri sözlügü̈. İstanbul: Anka yayınları.

Coşkun, E. (2009). Dünya sinemasında akımlar.Ankara. Ankara: Phoenix Yayınevi. 
Çalkıvik, S. (2006). Abbas Kiarostami'nin gözbebeği: Nema-ye Nazdik (Close-Up). CNBC-e Dergi.

Dabaşi, H. (2013). İran Sineması. (B. Aladağ, \& B. Kovulmaz, Çev.) İstanbul: Agora Kitaplığı.

Dayan, D. (2011). Klasik sinemanın tudor-kodu. (Der. ve Çev: Ertan Yılmaz). E. Yılmaz içinde, Filmde yöntem ve eleştiri (E. Yılmaz, Çev.). Ankara: De-ki Basım Yayın.

Deleuze, G., \& Guattari, F. (2005). A thousand plateaus: Capitalism and schizophrenia. (B. Massumi, Çev.) London: Bloomsbury.

Dolar, M. (2013). Sahibinin sesi. (B. Aksoy, Çev.) İstanbul: Metis Yayıncılık.

Erdoğan, i. (2007). Pozitivist metodoloji: Bilimsel araştırma tasarımı istatistiksel yöntemler analiz ve yorum. Ankara: Erk yayınları.

Ferahmend, A. (2007). Son dönem İran Sineması (Uluslararası başarısı) üzerine perspektifler. . R. Tapper içinde, Yeni Iran sineması: Siyaset,Temsil ve Kimlik (K. Sarısözen, Çev., s. 107-135). İstanbul: Kapı yayınları.

Geray, H. (2006). Toplumsal araştırmalarda nitel ve nicel yöntemlere giriş. Ankara: Siyasal kitabevi.

Gökçe, O. (2019). Klasik ve nitel içerik analizi: Felsefe, yöntem ve uygulama. Konya: Çizgi kitabevi.

Gültekin, G. (2018). Kırılgan Gerçeklik: Blow-Up Filminde Göstergeler ve Gerçeklik Bağı. Atatürk Üniversitesi Sosyal Bilimler Enstitüsü Dergisi, 22(3), 1711-1726.

Gültekin, G. (2020). Sinedigma: Sinemanın Zihinsel ve Toplumsal Gerçeklik Üretimi. SineFilozofi, 5(10), 704-721.

Gürata, A. (2010). Sinema ve kuram. S. Büker, \& G. Topçu içinde, Sinema: Tarih-Kuram-Eleştiri (s. 60-66). İstanbul: Kırmızı Kedi yayınları.

İpek, Ö. (2014). Hayatı kopyalamak: Abbas Kiarostami sineması üzerine düşünceler. H. Köse içinde, Kara Perde: Iran yönetmen sineması üzerine düşünceler (s. 118-133). İstanbul: Ayrıntı yayınları.

Kalari, M. (1999). Monsieur Kiarostami siz kimsiniz? Abbas Kiarostami'nin dünyası. 25. Kare(29), 63-66.

Kambur, A. (1999). Komşunun evi nerede? İranlı yönetmenler dışarı'da dolaşıyor. 25. Kare(28), 63-69.

Karasar, N. (2005). Bilimsel araştırma yöntemi. Ankara: Nobel Yayın Dağııım.

Kıran, Z., \& Kıran, A. (2000). Yazınsal okuma süreçleri. Ankara: Seçkin Yayınevi.

Kovacs, A. B. (2010). Modernizmi seyretmek: Avrupa sanat sineması 1950-1980. (Y. Ertan, Çev.) Ankara: De-ki Basım Yayım.

Kracauer, S. (2015). Film teorisi: Fiziksel gerçekliğin kurtuluşu. (Ö. Çelik, Çev.) İstanbul: Metis yayınları.

Metz, C. (1992). Aural objects. G. Mast, L. Braudy, \& M. Cohen içinde, Film Theory and Criticism: Introductory Readings (s. 313-316). NewYork: Oxford University.

Monaco, J. (2001). Bir film nasıl okunur? (E. Yılmaz, Çev.) İstanbul: Oğlak yayıncılık.

Moran, B. (2014). Edebiyat kuramları ve eleştiri. İstanbul: Illetişim yayınları. 
Neuman, W. (2014). Toplumsal Araştırma Yöntemleri 2: Nitel ve nicel yaklaşımlar. (S. Özge, Çev.) Ankara: Yayın odası.

Özön, N. (2000). Sinema, televizyon, video, bilgisayarlı sinema sözlüğü. İstanbul: Kabalcı yayınevi.

Ryan, M., \& Lenos, M. (2014). Film çözümlemesine giriş: Anlatı sinemasında teknik ve anlam. (S. Onat, Çev.) Ankara: Deki Basım Yayın.

Simmel, G. (2006). Bridge and door. D. Frisby, \& M. Featherstone içinde, On culture: Selected writings (s. 160-180). London: Sage Publications.

Sontag, S. (2011). Fotoğraf Üzerine. (O. Akınhay, Çev.) İstanbul: Agora Kitaplığı.

Tabakoğlu, M., \& Maden, Ş. (2019). Nokta metaforu ve vahdet üzerine eklektik bir metin: Noktatü'l Beyan Risalesi. . Abant Izzet Baysal Üniversitesi Ilahiyat Fakültesi Dergisi, 7(13), 61-93.

Tapper, R. (2007). Yeni Iran sineması: Siyaset, temsil ve kimlik. (K. Sarısözen, Çev.) İstanbul: Kapı yayınları. Timuçin, A. (2004). Felsefe sözlüğü. İstanbul: Bulut yayınları.

Wollen, P. (2013). Godard ve Karşı Sinema. Istanbul Arel Üniversitesi Illetişim Fakültesi Iletişim Çalışmaları, $77-87$.

Yıldırım, A., \& Şimşek, H. (2016). Sosyal bilimlerde nitel araştırma yöntemleri. Ankara: Seçkin yayıncılık.

Yücer, H. M. (2017). Vahdet-i Vücûd nazariyesinin izahında nokta sembolizmi ve Muhyiddin-i Rûmî'nin Temsîl-i Nokta adlı eseri. Journal of History Culture and Art Research, 6(2), 199 - 278.

Zizek, S. (2005). Yamuk Bakmak. (T. Birkan, Çev.) İstanbul: Metis Yayınları. 